\title{
NATIVE ARBUSCULAR MYCORRHIZAL FUNGAL COMMUNITY COMPOSITION FROM BARTIN PROVINCE, TURKEY
}

\author{
PALTA, Ş. ${ }^{*}-$ ÖZTÜRK, M. $^{2}-$ DE SOUZA, T. A. F. ${ }^{3}$ \\ ${ }^{1}$ Subdivision of Range Management, Division of Watershed Management, Department of Forest \\ Engineering, Faculty of Forestry, Bartin University, 74100 Bartın, Turkey \\ ${ }^{2}$ Division of Landscape Techniques, Department of Landscape Architecture, Faculty of \\ Forestry, Bartın University, 74100 Bartın, Turkey \\ ${ }^{3}$ Agrarian Science Centre, Department of Soils and Rural Engineering, Federal University of \\ Paraíba, 58397-000 Areia, Paraiba, Brazil \\ *Corresponding author \\ e-mail:spalta@bartin.edu.tr \\ (Received $28^{\text {th }}$ Feb 2018; accepted $10^{\text {th }}$ May 2018)
}

\begin{abstract}
The variety of the arbuscular mycorrhizal fungi (AMF) under the different forest stands is significant in terms of forest and rangeland ecosystems. In this study, dependent upon the morphological analyses, the diversity of the AMF within the pure oak forest (POF), fir-beech forest (FBF) stands, and gap in forest (GF) soils were compared in Bartın Province, Black Sea Region in northwestern of Turkey. The AMF community composition in POF, FBF and GF soil samples showed variation. Soil organic carbon, available $\mathrm{P}$, number of AMF spores, species richness, diversity index, and dominance index were the main parameters differing among the three studied environments. In particular, the most prevalent "order" in these soils was Glomerales. The most frequent AMF genus in the soils of all these fields was Glomus. Varieties in AMF diversity were due to the: (1) changes in soil characteristics (e.g. soil available $\mathrm{P}$ and organic carbon); and (2) plant communities in the study fields. These findings support the detailed knowledge of AMF community compositions in soils from Turkey, and introduce new comprehension in order to analyze the ecological processes including the AMF species and native plant species in the northwestern Black Sea Region of Turkey.
\end{abstract}

Keywords: Glomeromycota, native plant species, AMF diversity, AMF community composition, ecological processes

\section{Introduction}

Temperate broadleaf and mixed forests constitute several ecoregions within the northwestern Black Sea Region, also referred to as temperate climate terrestrial biome. The temperate climate terrestrial biome was defined by Knudsen et al. (2017) as a "type of forest, which involves tall mature trees, shade-tolerant understory, small mature trees, saplings, suppressed juvenile canopy trees, low growing woody plants and herbaceous plants". This ecoregion is composed of variable vegetation types (usually, classified as four-layered vegetation structure). The ecoregion has dominant broadleaf tree species (e.g., Quercus spp. L., Fagus spp. L., Acer spp. L., Betula spp. L.) and coniferous tree species (Pinus spp. L., Abies spp. Mill., and Picea spp. Mill.). However, it is still unclear whether these vegetation types and soil properties have positive impacts on the native arbuscular mycorrhizal fungal (AMF) community (de Souza and Freitas, 2017).

Symbiosis between plant species and AMF is probably the oldest plant-microbes mutualistic relationship (Brundrett, 2002; Parniske, 2008). AMF are important biological component of soil and are closely associated with many ecosystem processes, including: (1) Plant community composition; (2) Soil microbial communities' structure; 
(3) Host-plant physiology; and (4) Ecosystem homeostasis (Rillig, 2004; Closa and Goicoeche, 2011; Ortiz et al., 2015; de Souza and Freitas, 2017). They can establish a symbiotic mutualistic connection (with the majority of terrestrial plant species), that is featured by the occurrence of intracellular structures such as arbuscules (Smith and Read, 2008; Hodge and Storer, 2014). AMF also occurs in several terrestrial ecosystems, from forests to grasslands, and from agroecosystems to deserts (Öpik et al., 2006).

In fact, AMF provides water and mineral nutrients (e.g. nitrogen and phosphorus) to the host-plant while plants provide energy (e.g. carbohydrates) to the AMF (Smith and Smith, 2011; Hodge and Storer, 2014). As reported by Rillig (2004), the changes in the physiology (e.g. root exudates, photosynthesis) of the host plant that are induced by the AMF and nutrient uptake, can be conveyed to the ecosystem processes. These ecosystem processes can directly and indirectly affect the diversity of the arbuscular mycorrhizal fungi (AMF) community and their function by altering (1) soil properties and (2) plant community composition (Clapp et al., 1998; de Souza et al., 2016a; Esch et al., 2017; de Souza and Freitas, 2017). AMF community diversity is positively correlated with the plant richness as reported by Zubek et al. (2013). Therefore, decreasing the diversity of plants hosting the AMF community, leads to the reduction in the growth and proliferation of AMF at the sites lacking diversity of host-plant community (Burrows and Pfleger, 2002; de Souza et al., 2016b;).

Development of arbuscular mycorrhizal fungi can strongly be influenced by the plant community composition (de Souza and Freitas, 2017). AMF sporulation and colonization have significantly been affected by the plant diversity (Zubek et al., 2013; de Souza et al., 2016a, b). AMF colonization diminishes due to the host-plant response, soil type and availability of the soil nutrient (Smith and Read, 2008). It is emphasized that the type of forest and host plant might be the determinants for influencing the AMF spore density and biodiversity. The highest AMF spore density along the year was registered from the pine-oak mixed stand, pure pine and oak stands and the agricultural land respectively in India (Chaturvedi et al., 2012).

We investigated the AMF community composition under the pure oak forest (POF), fir-beech mixed forest (FBF) and gap in forest (GF) from Bartın Province, in Black Sea Region at the northwest of Turkey, using morphological analyses. We hypothesized the existence of a diversification of AMF community within the areas that present a high variability of plant community regarding the trees, shrubs and herbs. Several studies were conducted about the interactions among AMF, soil characteristics, and plant community (de Souza et al., 2016a, b; de Souza and Freitas, 2017). In order to achieve our target, we investigated the soil samples collected from the root zones to analyze the soil characteristics and AMF community composition.

\section{Materials and methods}

\section{Study sites}

The study areas were located in Bartın Province, Turkey. The study areas which are about $61 \mathrm{~km}$ away from the city centre of Bartın Province, are located within the $41^{\circ} 32^{\prime}$ Northern latitudes and $32^{\circ} 50^{\prime}$ Eastern longitudes (Fig. 1). These areas are located in the northwestern Black Sea Region. The exposures of the pure oak stand and mixed firbeech stand are South-East and North respectively. The gap in forest exposure is flat. The meteorological parameters used in this research were provided by the 
meteorological station of Bartin province. Relative humidity of the study areas ranges from $66.8 \%$ to $71.4 \%$ (Topay, 2003). The soil type is Ultisol according to the soil taxonomy of USDA (Kara et al., 2008; Palta et al., 2016). According to the Thornthwaite method, the study area is included into the humid mesothermal climate regime. Climatological data indicated that the annual average temperature is about $8.0^{\circ} \mathrm{C}$. On the other hand, the average temperatures of the two hottest months, July and August, are 18.0 and $17.5^{\circ} \mathrm{C}$, respectively. The mean annual precipitation in the study area is around $1534 \mathrm{~mm}$ (Şengönül et al., 2009).

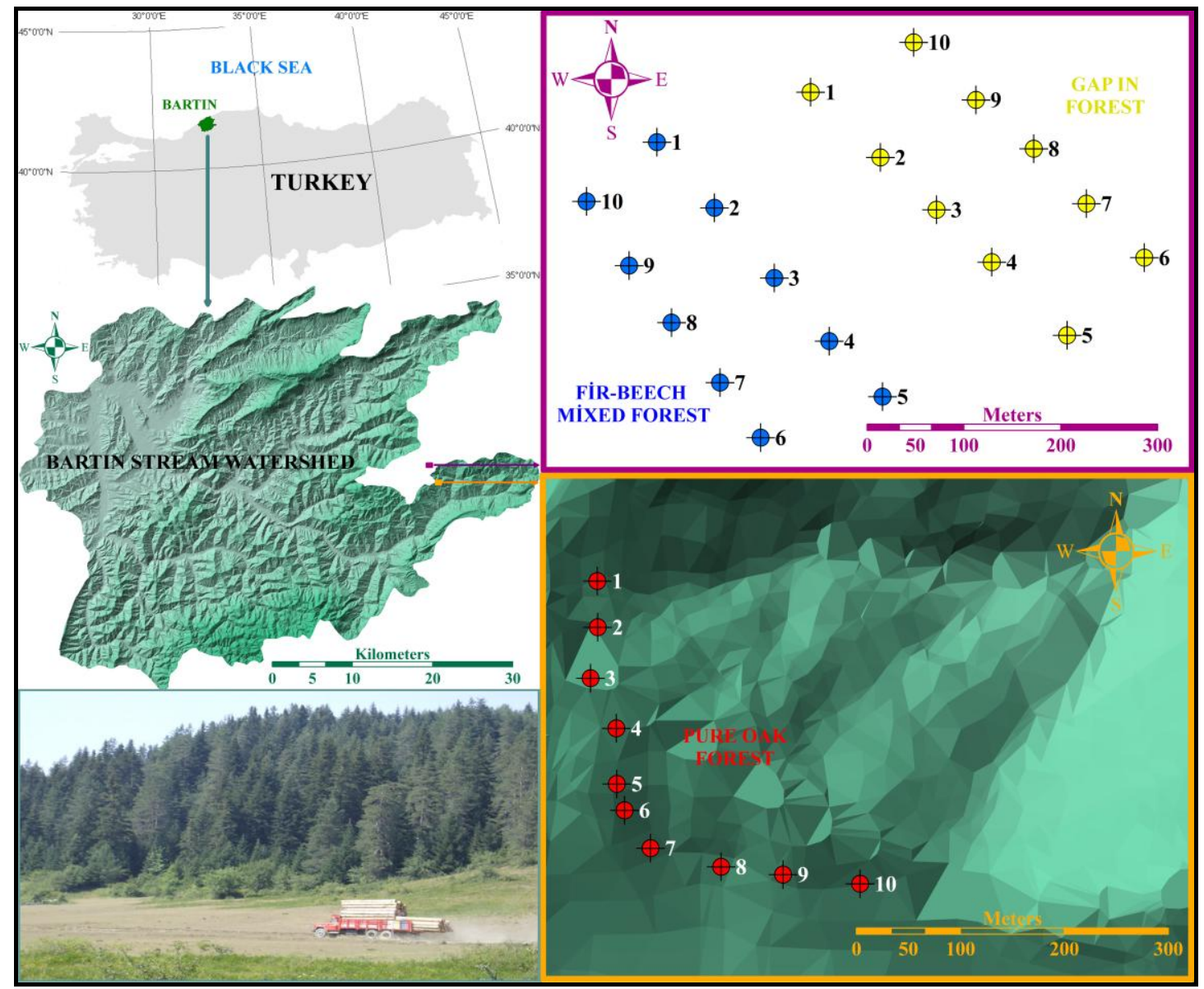

Figure 1. Sampling points of pure oak, fir-beech mixed forest stands and gap in forest within Bartin Stream Watershed, Turkey. A field photograph is also attached to the figure

Sampling was conducted on three different sites: (1) pure oak stand (1067 m asl.), (2) fir-beech mixed stand (1004 $\mathrm{m}$ asl.) and (3) gap in forest (976 m asl.). The following plant families were relatively common for the three areas: Fabaceae and Gramineae. The soil samples were collected from the rhizosphere of these plants. Table 1 demonstrates the explicit presentation of the plant taxons and their families within the study fields.

\section{Soil sampling}

Soil sampling was conducted during June and July 2015 (dry season). In each area, ten different composite root zone samples that involve soil and root fragments, were 
randomly taken from the near drip line and beyond (0-30 $\mathrm{cm}$ deep) of different plant taxa. The root zone samples from each treatment were sieved by a 2-mm sieve, put in polyethylene bags, and stored at $4^{\circ} \mathrm{C}$ until analyses dates. Thus, we analyzed 10 samples $(\mathrm{n}=10)$ for each studied area. In addition, along the dry season, the sampling was conducted since the fungal sporulation was estimated to be higher during that period in both arid and semi-arid ecosystems (Silva et al., 2014). The rhizosphere samples gathered from the study areas were separated into the portions in order to assess some of the chemical and physical characteristics of soil and AMF community.

Table 1. Plant species where soil samples were taken, in a pure oak forest (POF), fir-beech mixed forest (FBMF), and gap in forest (GF) in the northwestern Black Sea Region of Bartin Province, Turkey

\begin{tabular}{|c|c|c|c|c|}
\hline Family & Plant species & POF & FBMF & GF \\
\hline Apiaceae & Sanicula europaea $\mathrm{L}$. & & $\mathrm{X}$ & \\
\hline Cyperaceae & Carex sp. L. & & $\mathrm{X}$ & $\mathrm{X}$ \\
\hline Dennstaedtiacae & Pteridium aquilinum (L.) Kuhn in Kerstin & & $\mathrm{X}$ & \\
\hline Fabaceae & $\begin{array}{l}\text { Dorycnium graecum (L.) Ser } \\
\text { Lathyrus aphaca } \mathrm{L} \text {. } \\
\text { Lathyrus laxiflorus subsp. laxiflorus (Desf.) Kuntze } \\
\text { Lotus corniculatus } \mathrm{L} . \\
\text { Sophora jaubertii Spach }\end{array}$ & $\begin{array}{l}X \\
X \\
X\end{array}$ & & $\mathrm{X}$ \\
\hline Fagaceae & $\begin{array}{l}\text { Quercus petraea [Matt.] Liebl. } \\
\text { Fagus orientalis Lipsky }\end{array}$ & $\mathrm{X}$ & $X$ & \\
\hline Lamiaceae & $\begin{array}{l}\text { Ajuga reptans } \mathrm{L} \text {. } \\
\text { Lamium purpureum } \mathrm{L} \text {. }\end{array}$ & & $\begin{array}{l}X \\
X\end{array}$ & \\
\hline Pinaceae & Abies nordmanniana ssp. bornmülleriana Mattf. & & $\mathrm{X}$ & \\
\hline Poaceae & $\begin{array}{l}\text { Anthoxanthum odoratum L. subsp. odoratum } \\
\text { Calamagrostis arundinaceae (L.) Roth } \\
\text { Dactylis glomerata } \mathrm{L} \text {. } \\
\text { Festuca } \mathrm{sp} . \mathrm{L} \text {. } \\
\text { Hordeum violaceum Boiss. \& Huet } \\
\text { Poa bulbosa } \mathrm{L} .\end{array}$ & $\begin{array}{l}X \\
X \\
X \\
X\end{array}$ & $\mathrm{X}$ & $\begin{array}{l}X \\
X \\
X \\
X\end{array}$ \\
\hline lant species richnes & & 8 & 7 & 8 \\
\hline
\end{tabular}

\section{Isolation and identification of arbuscular mycorrhizal fungi}

Wet sieving methodology was referred during the isolation of the AMF spores (Gerdemann and Nicolson, 1963), which then was followed by the sucrose centrifugation (Jenkins, 1964). First of all, isolated spores were analyzed under water through a microscope. The spores were classified dependent upon their morphological characteristics. The species definition relied on the diagnosis based on Schenck and Perez (1990), and on scientific literatures about the new genera and families (i.e. Oehl et al., 2008; http://invam.caf.wvu.edu). For this study, we applied the classification suggested by Oehl et al. (2011), involving relatively recent identified new taxa (i.e. Goto et al., 2012; Sieverding et al., 2014). Furthermore, we investigated the AMF spore 
density and the species occurrence frequency $\left(\mathrm{FO}_{\mathrm{i}}\right)$ of each AMF species. $\mathrm{FO}_{\mathrm{i}}$ was computed based on this equation: $\mathrm{FO}_{\mathrm{i}}=\mathrm{n}_{\mathrm{i}} / \mathrm{N}$, where $\mathrm{n}_{\mathrm{i}}$ is the number of times an AMF species was examined and $\mathrm{N}$ is the total of AMF spores diagnosed from each treatment. Findings of $\mathrm{FO}_{\mathrm{i}}$ was classified dependent upon Zhang's frequency of occurrence classification: dominant $\left(\mathrm{FO}_{\mathrm{i}}>50 \%\right)$, most common $\left(31 \% \leq \mathrm{FO}_{\mathrm{i}} \leq 50 \%\right)$, common $\left(10 \% \leq \mathrm{FO}_{\mathrm{i}} \leq 30 \%\right)$ and rare $\left(\mathrm{FO}_{\mathrm{i}}<10 \%\right)$ (Zhang et al., 2004; de Souza et al., 2016c).

\section{Chemical and physical characteristics of soils}

The standard methods were applied for the analysis of the soil chemical and physical characteristics. These standard methods include the hydrometer method (Bouyoucos, 1962) for the identification of the soil particle size distribution. The $\mathrm{pH}$-meter (Rowell, 1994) was used for the identification of $\mathrm{pH}$ in 1:2.5 soil/water suspension. The electrical conductivity meter (Rhoades, 1982) was preferred for the determination of electrical conductivity in 1:5 soil/water suspension. The Walkley-Black wet oxidation method (Walkley and Black, 1934) and Kjeldahl method (Bremner and Mulvaney, 1982) was applied for the analysis of soil organic carbon and total nitrogen, respectively. The available phosphorus was determined based on Olsen et al. (1954). The Scheibler calcimeter method (Allison and Moodie, 1965) was practiced for identifying the $\mathrm{CaCO}_{3}$ content.

\section{Ecological and statistical analysis}

In order to analyze the significance of the overall variation in spore density, and soil properties among studied areas, the one-way ANOVA was performed. Data sets were conveyed (arc sin square root for percentage variables and logarithmic for other variables), but the findings were shown in their original scale of measurement (means with standard deviation) (Zar, 1984). When appropriate, the averages were compared by the Duncan test $(\mathrm{p}<0.05)$. AMF species richness, spore abundance, species occurrence frequency were also determined. Two ecological indices (Shannon and Simpson) were referred in this research (Shannon and Weaver, 1949; Simpson, 1949). Pearson correlation was also used to examine the relationships between AMF community composition and soil properties. The Statistical Package for the Social Sciences (SPSS), version 16.0 (SPSS 16.0, 2007) was applied for the statistical analyses.

\section{Results}

\section{Arbuscular mycorrhizal fungi community composition}

There were significant differences on number of AMF identified species $\left(F_{2,27}=21.85, p<0.001\right)$, number of spores $\left(F_{2,27}=28.45, p<0.001\right)$, diversity index $\left(F_{2,27}=13.98, p<0.001\right)$ and dominance index $\left(F_{2,27}=12.22, p<0.001\right)$ among the studied sites. It was recognized that the samples from gap in forest had included the highest AMF diagnosed species, with 7.0 identified species, followed by pure oak forest stand (2.2 AMF species) and fir-beech mixed forest stand (1.3 AMF species). The spore density of AMF was 7.6 spores $/ 25 \mathrm{~g}$ soil in pure oak forest stand; 2.8 spores $/ 25 \mathrm{~g}$ soil in fir-beech mixed forest stand; and 28.2 spores/25 g soil in gap in forest. Diversity $(\mathrm{H}$, Shannon's index) and dominance (C, Simpson's index) in the pure oak forest stand, firbeech mixed forest stand and gap in forest were 1.63 and $0.21 ; 1.12$ and 0.37 ; and 2.79 and 0.08 respectively (Table 2 ). 
Table 2. Average of AMF identified species (IS), number of spores (NS), diversity (H) and dominance index $(C)$ of each site (mean $\pm S D, n=10$ ) for each analyzed parameter

\begin{tabular}{c|c|c|c}
\hline Parameter & POF & FBMF & GF \\
\hline IS & $2.20 \pm 0.40^{\mathrm{b}}$ & $1.30 \pm 0.10^{\mathrm{b}}$ & $7.00 \pm 0.80^{\mathrm{a}}$ \\
NS $\left(25 \mathrm{~g} \mathrm{soil}^{-1}\right)$ & $7.60 \pm 3.71^{\mathrm{b}}$ & $2.80 \pm 1.98^{\mathrm{b}}$ & $28.20 \pm 13.19^{\mathrm{a}}$ \\
$\mathrm{H}$ & $1.63 \pm 0.32^{\mathrm{b}}$ & $1.12 \pm 0.15^{\mathrm{b}}$ & $2.79 \pm 0.28^{\mathrm{a}}$ \\
C & $0.21 \pm 0.02^{\mathrm{b}}$ & $0.37 \pm 0.03^{\mathrm{a}}$ & $0.08 \pm 0.02^{\mathrm{c}}$ \\
\hline
\end{tabular}

Pure oak forest stand (POF), fir-beech mixed forest stand (FBMF), and gap in forest (GF). Different letters mean significant differences by Duncan test $(p<0.05)$ after one-way ANOVA

Including all the study areas, 27 different AMF species were diagnosed belonging to 15 genera - Acaulospora (2), Cetraspora (1), Claroideoglomus (3), Corymbiglomus (1), Dentiscutata (3), Diversispora (2), Entrophospora (1), Funneliformis (2), Gigaspora (3), Glomus (2), Racocetra (1), Rhizoglomus (2), Scutellospora (2), and Septoglomus (1) (Table 3). Among the total AMF species, 2 (7.41\%) were classified as most common species: Glomus ambisporum and Glomus spp.; 6 (22.23\%) were classified as intermediate species: Acaulospora capsicula, A. foveata, Corymbiglomus tortuosum, Funneliformis caledonium, Rhizoglomus aggregatum, and $R$. fasciculatum; and 18 $(70.36 \%)$ were classified as exclusive: Cetraspora pellucida, Claroideoglomus claroideum, C. Lamellosum, C. Luteum, Dentiscutata erytrropus, D. heterogama, Dentiscutata spp., Diversispora eburnea, D. epigaea, Entrophospora infrequens, Funneliformis geosporum, Gigaspora albida, G. decipiens, G. gigantea, Racocetra verrucosa, Scutellospora calospora, Sclerocystis sinuosa, Scutellospora spp., and Septoglomus constrictum (Table 3; Figs. 2 and 3).

Table 3. Frequency of occurrence $\left(F O_{i}\right)$ of $A M F$ species of the pure oak forest stand (POF), fir-beech mixed forest stand (FBMF), and gap in forest (GF)

\begin{tabular}{|c|c|c|c|c|}
\hline \multirow{2}{*}{ AMF species } & \multicolumn{3}{|c|}{$\mathrm{FO}_{\mathrm{i}}{ }^{1}$ (classification $\left.^{2}\right)$} & \multirow{2}{*}{$\begin{array}{l}\text { Species } \\
\text { classification }\end{array}$} \\
\hline & POF & FBMF & GF & \\
\hline
\end{tabular}

Order Diversisporales

Family Acaulosporaceae

\begin{tabular}{l|c|c|c|c}
\hline Acaulospora capsicula Błaszk. & - & $4.7(\mathrm{R})$ & $9.9(\mathrm{R})$ & Intermediate \\
A. foveata Trappe \& Janos & $9.2(\mathrm{R})$ & - & $3.5(\mathrm{R})$ & Intermediate \\
\hline
\end{tabular}

Order Gigasporales

Family Dentiscutataceae

\begin{tabular}{|c|c|c|c|c|}
\hline $\begin{array}{l}\text { Dentiscutata erythropus (Koske \& C. Walker) C. } \\
\text { Walker \& D. Redecker }\end{array}$ & - & - & $1.0(\mathrm{R})$ & Exclusive \\
\hline $\begin{array}{l}\text { D. heterogama (T.H. Nicolson \& Gerd.) Sieverd., } \\
\text { F.A. Souza \& Oehl }\end{array}$ & - & - & $1.0(\mathrm{R})$ & Exclusive \\
\hline Dentiscutata spp. Sieverd., F.A. Souza \& Oehl & - & - & $1.0(\mathrm{R})$ & Exclusive \\
\hline
\end{tabular}

Family Diversisporaceae

Corymbiglomus tortuosum (N.C. Schenck \& G.S Sm.) Błaszk. \& Chwat

\begin{tabular}{|l|l|l|l|}
$5.3(\mathrm{R})$ & - & $1.0(\mathrm{R})$ & Intermediate \\
\hline
\end{tabular}




\begin{tabular}{|c|c|c|c|c|}
\hline $\begin{array}{l}\text { Diversispora eburnea (L.J. Kenn., J.C. Stutz \& J.B. } \\
\text { Morton) C. Walker \& A. Schüßler }\end{array}$ & - & - & $1.0(\mathrm{R})$ & Exclusive \\
\hline $\begin{array}{l}\text { D. epigaea (B.A. Daniels \& Trappe) C. Walker \& A. } \\
\text { Schüßler }\end{array}$ & - & - & $1.0(\mathrm{R})$ & Exclusive \\
\hline \multicolumn{5}{|l|}{ Family Gigasporaceae } \\
\hline $\begin{array}{l}\text { Cetraspora pellucida (T.H. Nicolson \& N.C. } \\
\text { Schenck) Oehl, F.A. Souza \& Sieverd. }\end{array}$ & - & - & $1.0(\mathrm{R})$ & Exclusive \\
\hline Gigaspora albida N.C. Schenck \& G.S. Sm. & - & - & $7.7(\mathrm{R})$ & Exclusive \\
\hline G. decipiens I.R. Hall \& L.K. Abbott & - & - & $1.0(\mathrm{R})$ & Exclusive \\
\hline G. gigantea (T.H. Nicolson \& Gerd.) Gerd. \& Trappe & - & - & $6.6(\mathrm{R})$ & Exclusive \\
\hline \multicolumn{5}{|l|}{ Family Racocetraceae } \\
\hline $\begin{array}{l}\text { Racocetra verrucosa (Koske \& C. Walker) Oehl, F.A. } \\
\text { Souza \& Sieverd. }\end{array}$ & - & - & $1.6(\mathrm{R})$ & Exclusive \\
\hline \multicolumn{5}{|l|}{ Family Scutellosporaceae } \\
\hline $\begin{array}{l}\text { Scutellospora calospora (T.H. Nicolson \& Gerd.) C. } \\
\text { Walker \& F.E. Sanders }\end{array}$ & - & - & $2.3(\mathrm{R})$ & Exclusive \\
\hline Scutellospora spp. C. Walker \& F.E. Sanders & - & - & 1.0 & Exclusive \\
\hline
\end{tabular}

\section{Order Glomerales}

\section{Family Entrophosporaceae}

\begin{tabular}{|c|c|c|c|c|}
\hline $\begin{array}{l}\text { Claroideoglomus claroideum (N.C. Schenck \& G.S. } \\
\text { Sm.) C. Walker \& Schüßler }\end{array}$ & - & - & $2.1(\mathrm{R})$ & Exclusive \\
\hline $\begin{array}{l}\text { C. lamellosum (Dalpé, Koske \& Tews) C. Walker \& } \\
\text { A. Schüßler }\end{array}$ & - & - & $1.4(\mathrm{R})$ & Exclusive \\
\hline $\begin{array}{l}\text { C. luteum (L.J. Kenn., J.C. Stutz \& J.B. Morton) C. } \\
\text { Walker \& A. Schüßler }\end{array}$ & - & - & $1.6(\mathrm{R})$ & Exclusive \\
\hline $\begin{array}{l}\text { Entrophospora infrequens (I.R. Hall) R.N. Ames \& } \\
\text { R.W. Schneider }\end{array}$ & - & - & $1.0(\mathrm{R})$ & Exclusive \\
\hline
\end{tabular}

\section{Family Glomeraceae}

\begin{tabular}{|c|c|c|c|c|}
\hline $\begin{array}{l}\text { Funneliformis caledonium (T.H. Nicolson \& Gerd.) } \\
\text { C. Walker \& Schüßler }\end{array}$ & $10.5(\mathrm{C})$ & - & $2.0(\mathrm{R})$ & Intermediate \\
\hline $\begin{array}{l}\text { F. geosporum (T.H. Nicolson \& Gerd.) C. Walker \& } \\
\text { Schüßler }\end{array}$ & - & - & $6.6(\mathrm{R})$ & Exclusive \\
\hline Glomus ambisporum G.S. Sm. \& N.C. Schenck & $32.9(\mathrm{MC})$ & $26.4(\mathrm{C})$ & $6.6(\mathrm{R})$ & Generalists \\
\hline Glomus spp. Tul. \& C. Tul. & $21.0(\mathrm{C})$ & $50.0(\mathrm{D})$ & $18.7(\mathrm{C})$ & Generalists \\
\hline $\begin{array}{l}\text { Rhizoglomus aggregatum (N.C. Schenck \& G.S. Sm.) } \\
\text { Sieverd., G.A. Silva \& Oehl }\end{array}$ & - & $18.9(\mathrm{C})$ & $9.8(\mathrm{R})$ & Intermediate \\
\hline R. fasciculatum (Thaxt.) Sieverd., G.A. Silva \& Oehl & $21.1(\mathrm{C})$ & - & $6.0(\mathrm{C})$ & Intermediate \\
\hline Sclerocystis sinuosa Gerd. \& B.K. Bakshi & - & - & $1.6(\mathrm{R})$ & Exclusive \\
\hline $\begin{array}{l}\text { Septoglomus constrictum (Trappe) Sieverd., G.A. } \\
\text { Silva \& Oehl }\end{array}$ & - & - & $1.0(\mathrm{R})$ & Exclusive \\
\hline
\end{tabular}

${ }^{1} \mathrm{FO}_{\mathrm{i}}=\mathrm{n}_{\mathrm{i}} / \mathrm{N}$, where $\mathrm{n}_{\mathrm{i}}$ is the number of times an AMF species were encountered and $\mathrm{N}$ is the total of AMF spores observed from each study field; ${ }^{2}$ Classification of AMF frequency of occurrence suggested by Zhang et al. (2004): R-rare (FO < 10\%); C-common $(10 \% \leq \mathrm{FO} \leq 30 \%)$; MC-most common $(31 \% \leq \mathrm{FO} \leq 50 \%)$; and D-dominant (FO > 50\%); and ${ }^{3}$ Species classification suggested by Stürmer and Siqueira (2011) most common (present in all fields), intermediate (present in 2 fields) or exclusive (present in only one field). 


\section{Chemical and physical properties of soils}

All the chemical and physical properties of soil varied significantly among the studied areas. The highest values of organic carbon, available phosphorous $(\mathrm{P})$, total nitrogen $(\mathrm{N})$ and soil moisture were found in the gap in forest (GP). Soil $\mathrm{pH}$ was higher in the fir-beech mixed forest stand (FBMF) compared to the other treatments. For the physical properties, we found the highest values of sand, clay and silt in the pure oak forest (PO) stand (Table 4).

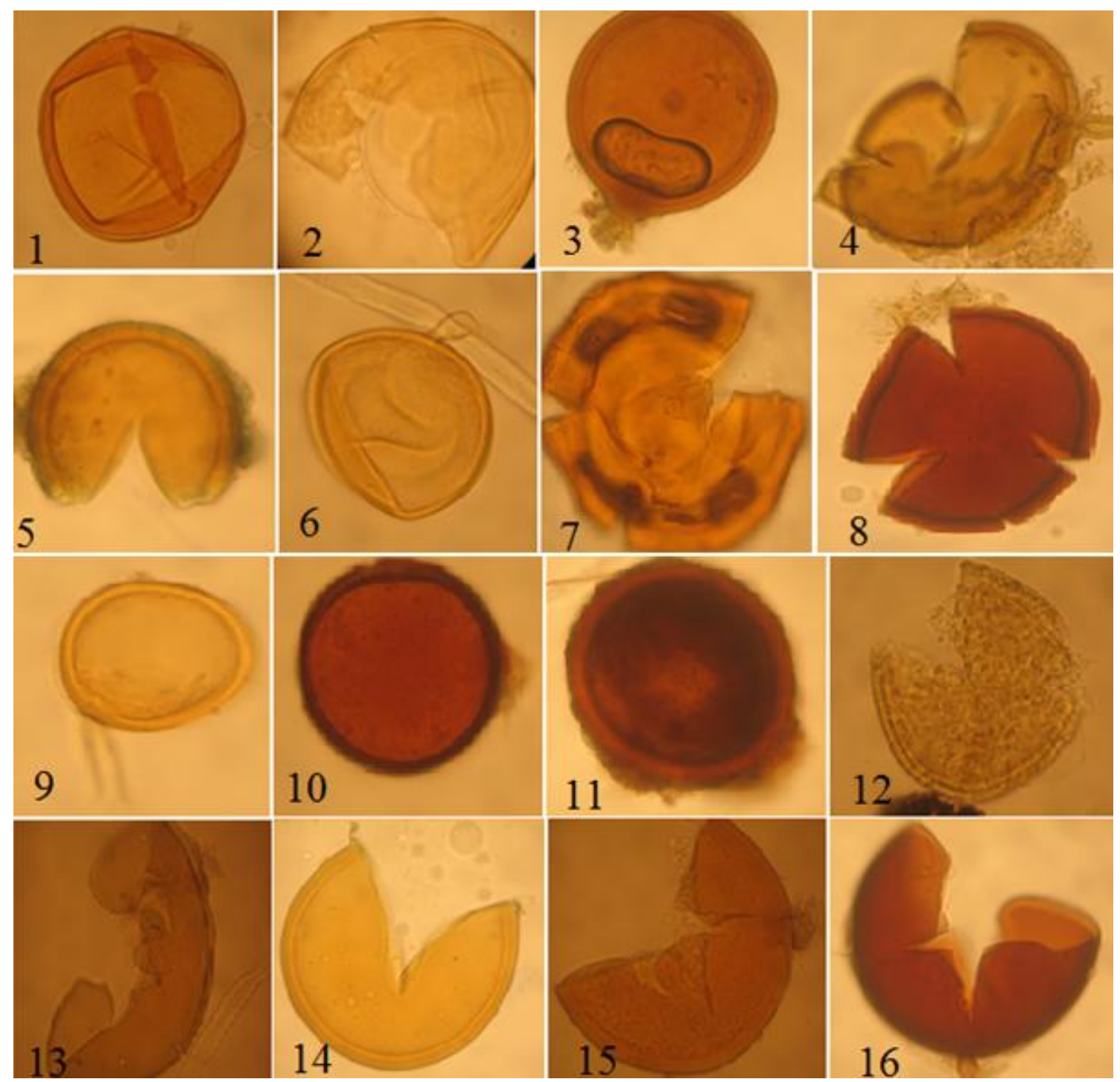

Figure 2. AMF spores 1) Acaulospora capsicula (150 $\left.\mu m^{*}\right)$, 2) Acaulospora foveata (280-360

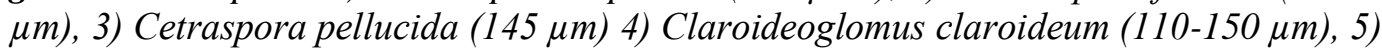
Claroideoglomus lamellosum (150 $\mu \mathrm{m})$, 6) Claroideoglomus luteum $(140 \mu \mathrm{m}), 7)$ Dentiscutata

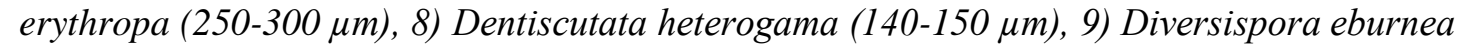
$(100 \mu \mathrm{m}), 10)$ Diversispora epigaea $(135 \mu \mathrm{m}), 11)$ Diversispora tortuosa $(200 \mu \mathrm{m}), 12)$

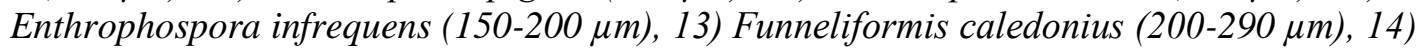

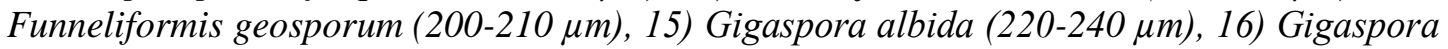
decipiens (200-250 $\mu \mathrm{m})$. *Diameter 


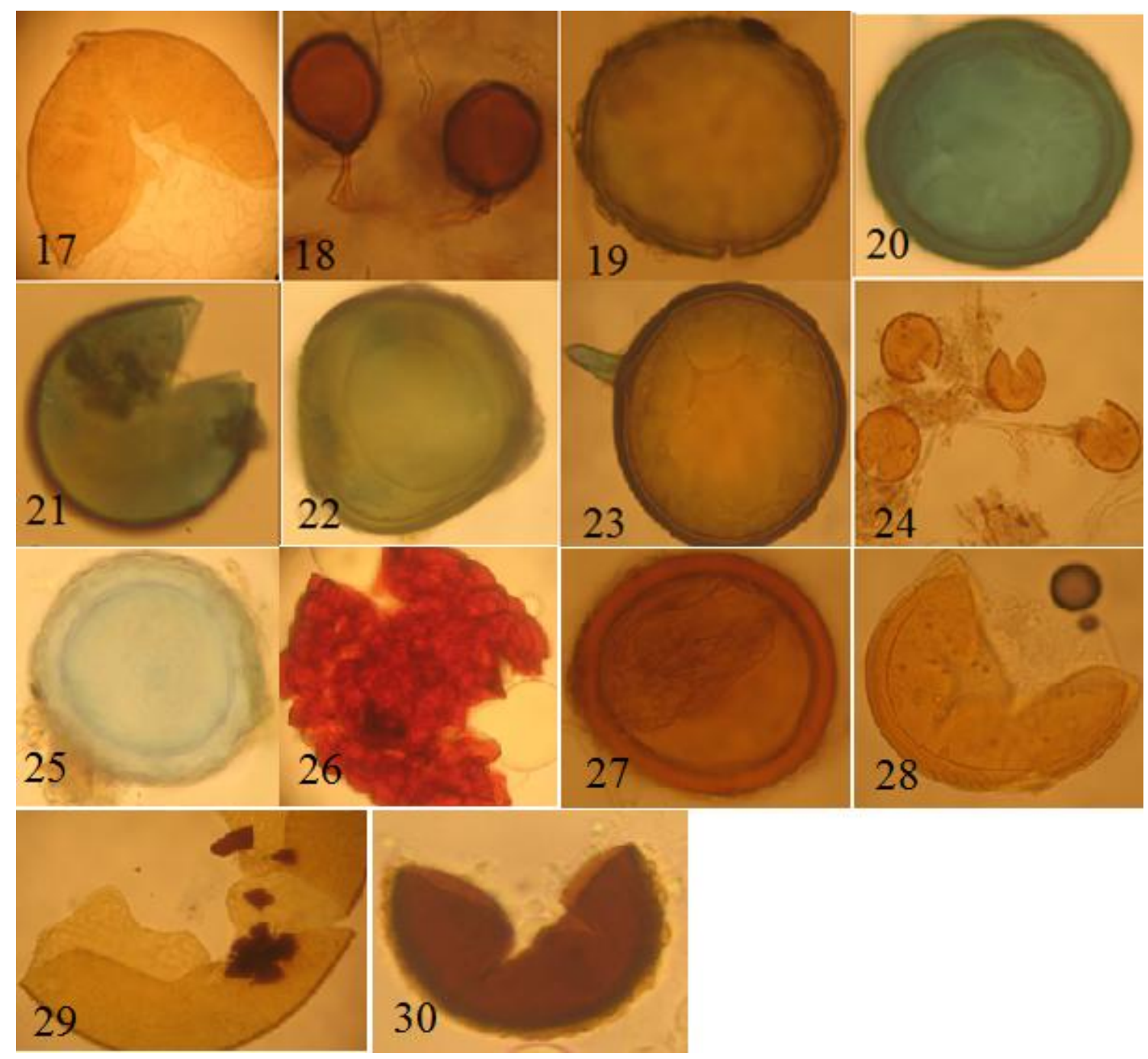

Figure 3. 17) Gigaspora gigantea (450-650 $\mu \mathrm{m} *)$, 18) Glomus ambisporum (50 $\mu \mathrm{m}), 19)$

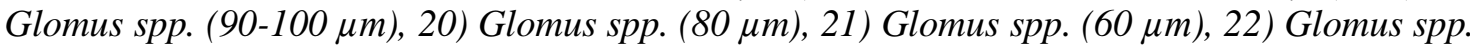

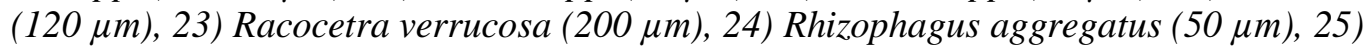

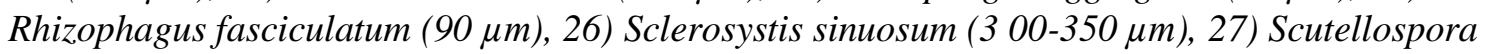

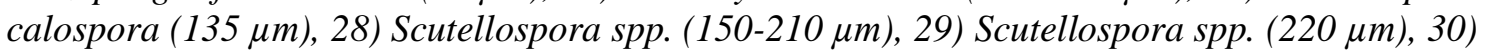
Septoglomus constrictum $(50-70 \mu \mathrm{m})$. *Diameter

\section{Correlation analysis}

According to the correlation analysis, a positive correlation was found between the AMF spore density, and organic carbon, available phosphorus, total nitrogen and the moisture of soil with $r$-values; $0.683,0.534,0.661$ and 0.660 , respectively (Table 5).

\section{Discussion}

\section{Arbuscular mycorrhizal fungi}

Our results indicate that the changes in arbuscular mycorrhizal community were led by differences in: (1) plant community composition among the gap in forest and the other two studied forested sites; and (2) soil properties among all the studied sites in the 
northwestern Black Sea Region, Turkey. In fact, these two factors may influence AMF community structure in different ways (Olsson et al., 2010; Zubek et al., 2016; de Souza and Freitas, 2017). In the pure oak forest and fir-beech mixed forest, both plant community and soil properties significantly affected the AMF diversity and dominance. These results are consistent with the former studies (Gehring, 2003; Heinemeyer et. al., 2004; Shukla et al., 2009; Shi et al., 2014), and support our hypothesis that a diversified AMF community is associated with the areas that present a high diversity of plant community involving trees, shrubs and herbs. As a consequence, areas with low diversity of plant species (pure oak forest and gap in forest) are likely to decrease mycorrhizal root colonization (Johnson, 2010; Shi et al., 2014).

Table 4. Mean of physical and chemical soil characteristics (mean $\pm S D, n=10$ ) of the studied areas

\begin{tabular}{c|c|c|c}
\hline Soil characteristics & POF & FBMF & GF \\
\hline Sand (\%) & $35.20( \pm 6.51)^{\mathrm{a}}$ & $47.20( \pm 3.32)^{\mathrm{b}}$ & $41.05( \pm 7.51)^{\mathrm{b}}$ \\
Clay (\%) & $27.30( \pm 5.46)^{\mathrm{a}}$ & $18.60( \pm 2.12)^{\mathrm{b}}$ & $20.05( \pm 5.25)^{\mathrm{b}}$ \\
Silt (\%) & $37.50( \pm 3.95)^{\mathrm{a}}$ & $34.20( \pm 2.35)^{\mathrm{b}}$ & $38.90( \pm 3.60)^{\mathrm{a}}$ \\
$\mathrm{pH}\left(\mathrm{H}_{2} \mathrm{O}\right)$ & $5.09( \pm 0.16)^{\mathrm{a}}$ & $5.33( \pm 0.36)^{\mathrm{a}}$ & $5.30( \pm 0.58)^{\mathrm{a}}$ \\
Soil texture & Clay Loam & Loam & Loam \\
$\mathrm{CaCO}_{3}(\%)$ & $0.26( \pm 0.09)^{\mathrm{a}}$ & $0.29( \pm 0.08)^{\mathrm{a}}$ & $0.27( \pm 0.12)^{\mathrm{a}}$ \\
Electrical conductivity (dS m $\left.{ }^{-1}\right)$ & $0.03( \pm 0.01)^{\mathrm{a}}$ & $0.03( \pm 0.02)^{\mathrm{a}}$ & $0.06( \pm 0.02)^{\mathrm{b}}$ \\
Organic carbon (\%) & $5.18( \pm 0.73)^{\mathrm{a}}$ & $5.46( \pm 1.37)^{\mathrm{a}}$ & $8.10( \pm 0.81)^{\mathrm{b}}$ \\
Available P (mg/kg) & $46.92( \pm 14.48)^{\mathrm{a}}$ & $50.07( \pm 8.18)^{\mathrm{a}}$ & $71.92( \pm 16.98)^{\mathrm{b}}$ \\
Total N (mg/lt) & $0.39( \pm 0.08)^{\mathrm{a}}$ & $0.41( \pm 0.09)^{\mathrm{a}}$ & $0.56( \pm 0.13)^{\mathrm{b}}$ \\
Soil moisture (\%) & $33.02( \pm 9.65)^{\mathrm{a}}$ & $26.53( \pm 7.24)^{\mathrm{a}}$ & $43.37( \pm 7.54)^{\mathrm{b}}$ \\
\hline
\end{tabular}

The values in the same row that are followed by the different letter demonstrate significant $(p<0.05)$ differences between the means

Table 5. Pearson's correlation coefficient values ( $r$-values) for AMF spore density (SD), soil organic carbon $\left(C_{\text {org }}\right)$, available phosphorous $(A P)$, total nitrogen $(T N)$, and soil moisture (SM) from the studied areas $(n=30)$

\begin{tabular}{c|c|c|c|c|c}
\hline Variables & SD & $\mathbf{C}_{\text {org }}$ & AP & TN & SM \\
\hline SD & - & $0.683^{* *}$ & $0.534^{* *}$ & $0.661^{* *}$ & $0.660^{* *}$ \\
Corg $_{\text {org }}$ & & & $0.637^{* *}$ & $0.812^{* *}$ & $0.375^{* *}$ \\
AP & & & & $0.709^{* *}$ & $0.409^{*}$ \\
TN & & & & & $0.395^{*}$ \\
\hline
\end{tabular}

Asterisks indicate significant differences by Pearson correlation analysis $\left({ }^{*} p<0.05 ; * * p<0.01\right)$

The variety in the AMF community structure among the study areas is due to the decreased vegetation species richness, decreased spore density, decreased biodiversity of arbuscular mycorrhizal fungi species (diversity index), and increased canopy closure of the stands. According to some particular studies also (e.g. Heinemeyer et al., 2004; Shukla et al., 2009; Shi et al., 2014), we hypothesize that the below factors may be drivers of the results observed for the AMF community composition. First, shade may have reduced the carbon allocation from shrubs and herbs by mycorrhizas. Thus, 
increasing canopy closure above understory may have reduced light intensity below understory and decreased the photosynthetic ability of host-plants (e.g. Anthoxanthum odoratum L, Carex sp. L., Dactylis glomerata L., Festuca sp. L., Hordeum violaceum Boiss \& Huet., Lathyrus aphaca L., and Sophora jauberii Spach). Consequently, these two processes may have reduced AM colonization and spore abundance (Heinemeyer et al., 2004; Shukla et al., 2009).

\section{Chemical and physical properties of soils}

The results of soil analysis revealed that some of the soil chemical and physical characteristics altered within the study areas. The results observed in the Black Sea Region indicated that the soil $\mathrm{pH}\left(\mathrm{H}_{2} \mathrm{O}\right)$ of forest, tillage and rangeland ranged from 5.0 to 7.8 (Korkanç, 2003; Kara et al., 2008; Şengönül et al., 2009; Palta et al., 2012, 2013). Compatible with the findings of the former studies, our results indicated that the average soil $\mathrm{pH}\left(\mathrm{H}_{2} \mathrm{O}\right)$ values of the pure oak stand, the fir-beech stand and the gap in the forest, were 5.09, 5.33 and 5.30, respectively (Table 5).

The observed results demonstrated that the soil organic carbon contents ranged from 4.2 to $7.3 \%$ in the rangelands of the Black Sea Region (Okatan, 1987; Şengönül, et al., 2009; Palta et al., 2012, 2013). The average soil organic carbon contents were determined for the pure oak stand, the fir-beech stand and the gap in the forest as $5.18 \%, 5.46 \%, 8.10 \%$, respectively (Table 5). In this study, the highest organic carbon content was found for the gap in the forest. This may be due to the exposure, slope and non-grazing in the study area. In addition, the gap in the forest field was relatively flat land but the stands were located on the sloping land. The toe of slope positions had superior soil organic carbon content due to the higher infiltration rate (Guzman and AlKaisi, 2011) and soil erosion (Gregorich et al., 1998). The highest number of forage legumes were found in the gap in the forest (Şengönül et al., 2009) and it was stated that legumes could supply nitrogen thanks to the biological fixation of $\mathrm{N}$ from the atmosphere (Monegat, 1991) and increased the rates of accumulation of both soil nitrogen and carbon (Knops and Tilman, 2000). In addition, it was stated that the soil organic carbon was influenced by the soil properties (Tisdall and Oades, 1982; Kay, 1998; Jones et al., 2004).

\section{Conclusions}

This research demonstrated that the arbuscular mycorrhizal fungi biodiversity was influenced by the stand types; the pure oak stand, mixed fir-beech stand and the gap in forest. It was showed that the higher AMF biodiversity and associated AMF spore density were determined for the gap in forest, pure oak forest stand and fir-beech mixed forest stand, respectively. Furthermore, AMF spore density was positively correlated with the organic carbon content, available phosphorus, total nitrogen and moisture of soil. The main results of this study overall indicate: (1) changes in plant community compositions and soil properties alter the AMF diversity and community structure; and (2) plant community composition below the understory can influence AMF biodiversity indicating that the overall vegetation diversity is significant for the AMF diversity. The studies on AMF are currently and relatively inadequate in the northwestern Black Sea Region. Therefore, similar researches should spatially be spread and favoured within the region in order to delineate the map of AMF distribution. Besides, genus of native AMF should be isolated 
and reproduced to be utilized for the prospective plantation studies. Consequently, sustainable management of the forest and rangeland interaction fields will be achieved.

\section{REFERENCES}

[1] Allison, L. E, Moodie, C. D. (1965): Carbonate. - In: Black, C. A. (ed.) Methods of Soil Analysis, pp. 1379-1396. American Society of Agronomy, Wisconsin, USA.

[2] Bouyoucos, G. J. (1962): Hydrometer method improved for making particle size analyses of soils. - Agronomy Journal 54: 464-465.

[3] Bremner, J. M., Mulvaney, C. S. (1982): Nitrogen-Total. - In: Page, A. L. (ed.) Methods of Soil Analysis. Part 2: Chemical and Microbiological Properties, pp. 595-622. SSSA, Madison, USA.

[4] Brundrett, M. C. (2002): Coevolution of roots and mycorrhizas of land plants. - New Phytologist 154: 275-304.

[5] Burrows, R. L., Pfleger, F. L. (2002): Host responses to AMF from plots differing in plant diversity. - Plant and Soil 240: 169-179.

[6] Chaturvedi, S., Tewari, V., Sharma, S., Oehl, F., Wiemken, A., Prakash, A., Sharma, A. K. (2012): Diversity of arbuscular mycorrhizal fungi in oak pine forests and agricultural land prevalent in the Kumaon Himalayan Hills, Uttarakhand, India. - British Microbiology Research Journal 2(2): 82-96.

[7] Clapp, J. P., Helgason, T., Daniell, T. J., Young, J. P. W. (1998): Genetic Studies of Structure and Diversity of Arbuscular Mycorrhizal Fungal Communities. - In: Varma, A., Hock, B. (eds.) Mycorrhiza Structure, Function Molecular Biology and Biotechnology, $2^{\text {nd }}$ ed., pp. 202-223. Springer, New York, USA.

[8] Closa, I., Goicoeche, N. (2011): Infectivity of arbuscular mycorrhizal fungi in naturally regenerating, unmanaged and clear-cut beech forests. - Pedosphere 21(1): 65-74.

[9] De Souza, T. A. F., Freitas, H. (2017): Arbuscular mycorrhizal fungi community assembly in the Brazilian tropical seasonal dry forest. - Ecological Processes 6: 2-10.

[10] De Souza, T. A. F., Rodriguez-Echeverría, S., Andrade, L. A., Freitas, H. (2016a): Arbuscular mycorrhizal fungi in Mimosa tenuiflora (Willd.) Poir from Brazilian semiarid. - Brazilian Journal of Microbiology 47: 359-366.

[11] De Souza, T. A. F., Rodriguez-Echeverría, S., Andrade, L. A., Freitas, H. (2016b): Could biological invasion by Cryptostegia madagascariensis alter the composition of the arbuscular mycorrhizal fungal community in semi-arid Brazil? - Acta Botanica Brasilica 30(1): 93-101.

[12] De Souza, T. A. F., Rodriguez-Echeverría, S., de Andrade, L. A., Freitas, H. (2016c): Could biological invasion by Cryptostegia madagascariensis alter the composition of the arbuscular mycorrhizal fungal community in semi-arid Brazil? - Acta Botanica Brasilica 30(1): 93-101.

[13] Esch, E. H., Lipson, D., Cleland, E. E. (2017): Direct and indirect effects of shifting rainfall on soil microbial respiration and enzyme activity in a semi-arid system. - Plant and Soil 411(1): 333-346.

[14] Gehring, C. A. (2003): Growth responses to arbuscular mycorrhizae by rain forest seedlings vary with light intensity and tree species. - Plant Ecology 167: 127-139.

[15] Gerdemann, J. W., Nicolson, T. H. (1963): Spores of mycorrhizal Endogone species extracted from soil by wet sieving and decanting. - Transactions of the British Mycological Society 1: 43-66.

[16] Goto, B. T., Silva, G. A., Assis, D. M. A., Silva, D. K. A., Souza, R. G.; Ferreira, A. C. A., Jobim, K., Mello, C. M. A., Vieira, H. E. E., Maia, L. C., Oehl, F. (2012): Intraornatosporaceae (Gigasporales), a new family with two new genera and two new species. - Mycotaxon 119: 117-132. 
[17] Gregorich, E. G., Greer, K. J., Anderson, D. W., Liang, B. C. (1998): Carbon distribution and losses: erosion and deposition effects. - Soil and Tillage Research 47: 291-302.

[18] Guzman, J. G., Al-Kaisi, M. M. (2011): Landscape position effect on selected soil physical properties of reconstructed prairies in southcentral Iowa. - Journal of Soil and Water Conservation 66(3): 183-191.

[19] Heinemeyer, A., Ridgway, K. P., Edwards, E. J., Benham, D. G., Young, J. P. W., Fitter, A. H. (2004): Impact of soil warming and shading on colonization and community structure of arbuscular mycorrhizal fungi in roots of a native grassland community. Global Change Biology 10: 52-64.

[20] Hodge, A., Storer, K. (2014): Arbuscular mycorrhizal and nitrogen: implications for individual plants through to ecosystems. - Plant and Soil 386: 1-19.

[21] Jenkins, W. R. (1964): A rapid centrifugal flotation technique for separating nematodes from soil. - Plant Disease Reporter 48(9): 692.

[22] Johnson, N. C. (2010): Resource stoichiometry elucidates the structure and function of arbuscular mycorrhizas across scales. - New Phytologist 185: 631-647.

[23] Jones, R. J. A., Hiederer, R., Rusco, E., Loveland, P. J., Montanarella, L. (2004): The map of soil organic carbon in topsoils in Europe, Version 1.2, September 2003: explanation of special publication Ispra 2004 no, 72 (S.P.I.04.72). - European Soil Bureau Research Report No 17, EUR 21209 EN. Office for Official Publications of the European Communities, Luxembourg.

[24] Kara, Ö., Bolat, İ., Çakıroğlu, K., Öztürk, M. (2008): Plant canopy effects on litter accumulation and soil microbial biomass in two temperate forests. - Biology and Fertility of Soils 45: 193-198.

[25] Kay, B. D. (1998): Soil Structure and Organic Carbon: A Review. - In: Lal, R., Kimble, J. M., Follet, R. F. (eds.) Soils Processes and The Carbon Cycle. Advances in Soil Science, pp. 169-197. CRC Lewis Publishers, Boca Raton, Florida, USA.

[26] Knops, J. M. H., Tilman, D. (2000): Dynamics of soil nitrogen and carbon accumulation for 61 years after agricultural abandonment. - Ecology 81(1): 88-98.

[27] Knudsen, M. T., Hermansen, J. E., Cederberg, C., Herzog. F., Vale, J., Jeanneret, P., Sarthou, J., Friedel, J. K., Balázs, K., Fjellstad, W., Kainz, M., Wolfrum, S., Dennis, P. (2017): Characterization factors for land use impacts on biodiversity in life cycle assessment based on direct measures of plant species richness in European farmland in the 'Temperate Broadleaf and Mixed Forest' biome. - Science of the Total Environment 580: 358-366.

[28] Korkanç, S. Y. (2003): Bartın Yöresinde Arazi Kullanım Sorunları ve Çözüm Önerileri (Iskalan Deresi Yağış Havzası Örneği). - Doktora Tezi, İstanbul Üniversitesi, Fen Bilimler, Enstitüsü, Havza Amenajmanı Anabilim Dalı, İstanbul, Türkiye.

[29] Monegat, C. (1991): Plantas de cobertura do solo: características e manejo em pequenas propriedades. $2^{\text {nd }}$ ed. - Ed. do autor, Chapecó, S. C.

[30] Oehl, F., Souza, F. A., Sieverding, E. (2008): Revision of Scutellospora and description of five new genera and three new families in the arbuscular mycorrhiza-forming Glomeromycetes. - Mycotaxon 106: 311-360.

[31] Oehl, F., Sieverding. E., Palenzuela, J., Ineichen, K., Silva, G. A. (2011): Advances in Glomeromycota taxonomy and classification. - IMA Fungus 2: 191-199.

[32] Okatan, A. (1987): Trabzon Meryemana Deresi Yağış Havzası Alpin Meralarının Bazı Fiziksel ve Hidrolojik Toprak özellikleri ile Vejetasyon Yapısı Üzerine Araştırmalar. Doktora Tezi. T. C. Tarım ve Köyişleri Bakanlığı Orman Genel Müdürlügü̆, Yayın No: 664, Seri No: 62, Ankara.

[33] Olsen, S. R., Cole, C. V., Watanabe, F. S., Dean, L. A. (1954): Estimation of Available Phosphorus in Soils by Extraction with Sodium Bicarbonate. - U.S. Department of Agriculture, Circular No: 939, Washington, USA. 
[34] Olsson, P. A., Rahm, J., Aliasgharzad, N. (2010): Carbon dynamics in mycorrhizal symbioses is linked to carbon costs and phosphorus benefits. - FEMS Microbiology Ecology 72: 125-131.

[35] Öpik, M., Moora, M., Liira, J., Zobel, M. (2006): Composition of root-colonizing arbuscular mycorrhizal fungal communities in different ecosystems around the globe. Journal of Ecology 94: 778-90.

[36] Ortiz, N., Armada, E., Duque, E., Roldán, A., Azcón, A. (2015): Contribution of arbuscular mycorrhizal fungi and/or bacteria to enhancing plant drought tolerance under natural soil conditions: Effectiveness of autochthonous or allochthnous strains. - Journal of Plant Physiology 174: 87-96.

[37] Palta, Ş., Demir, S., Şengönül, K., Kara, Ö., Şensoy, H. (2012): Determination of Arbuscular Mycorrhizal Fungi (Amf) From Gramineae Family Plants in Ardıç Rangeland in Bartın Province. - Bartın University, Journal of the Bartın Faculty of Forestry 14(22): 72-81.

[38] Palta, Ş., Kara, Ö., Demir, S., Şengönül, K., Şensoy, H. (2013): Effects of soil properties and botanic composition on arbuscular mycorrhizal fungus (AMF) from Gramineae family plants. - Bartın University, Journal of the Bartın Faculty of Forestry 15(1-2): 2231.

[39] Palta, Ş., Genç Lermi, A., Beki, R. (2016): The effect of different land uses on arbuscular mycorrhizal fungi in the northwestern Black Sea Region. - Environmental Monitoring and Assessment 188(350): 1-13.

[40] Parniske, M. (2008): Arbuscular mycorrhiza: the mother of plant root endosymbioses. Nature Reviews Microbiology 6: 763-775.

[41] Rhoades, J. D. (1982): Soluble Salts. - In: Page, A. L. (ed.) Methods of Soil Analysis. Part 2: Chemical and Microbiological Properties, pp. 149-157. - SSSA, Madison, USA.

[42] Rillig, M. C. (2004): Arbuscular mycorrhizae and terrestrial ecosystem processes. Ecology Letters 7: 740-754.

[43] Rowell, D. L. (1994): Soil Science: Methods \& Applications. - Longman Scientific and Technical, Singapore.

[44] Shannon, C. E., Weaver, W. (1949): The Mathematical Theory of Communication. University of Illinois Press, Urbana, USA.

[45] Shi, G., Liu, Y., Johnson, N. C., Olsson, P. A., Mao, L., Cheng, G., Jiang, S., An, L., Du, G., Feng, H. (2014): Interactive influence of light intensity and soil fertility on rootassociated arbuscular mycorrhizal fungi. - Plant and Soil 378: 173-188.

[46] Schenck, N. C., Perez, Y. (1990): Manual for the Identification of VA Mycorrhizal Fungi. - International Culture Collection of VA Mycorrhizal Fungi (INVAM), University of Florida. $2^{\text {nd }}$ ed. Gainesville, USA.

[47] Shukla, A., Kumar, A., Jha, A., Chaturvedi, O. P., Prasad, R., Gupta, A. (2009): Effects of shade on arbuscular mycorrhizal colonization and growth of crops and tree seedlings in Central India. - Agroforestry Systems 76: 95-109.

[48] Sieverding, E., Silva, G. A., Berndt, R., Oehl, F. (2014): Rhizoglomus, a new genus of the Glomeraceae. - Mycotaxon 129: 373-386.

[49] Silva, I. R., Mello, C. M. A., Neto, R. A. F., Silva, D. K. A., Melo, A. L., Oehl, F., Maia, L. C. (2014): Diversity of arbuscular mycorrhizal fungi along an environmental gradient in the Brazilian semiarid. - Applied Soil Ecology 84: 166-175.

[50] Simpson, E. H. (1949): Measurement of diversity. - Nature 163: 688.

[51] Smith, S. E., Read, D. J. (2008): Mycorrhizal Symbiosis, $3^{\text {rd }}$ ed. - Academic Press, London, UK.

[52] Smith, S. E., Smith, F. A. (2011): Roles of arbuscular mycorrhizas in plant nutrition and growth: new paradigms from cellular and ecosystem scales. - Annual Review of Plant Biology 62: 227-250.

[53] SPSS Inc. (2007): SPSS for Windows, Version 16.0. - SPSS Inc, Chicago. 
[54] Şengönül, K., Kara, Ö., Palta, Ş., Şensoy, H. (2009): Determination of some quantitative properties of range vegetation and ecological conditions in Bartın Uluyayla. - Bartın University, Journal of the Bartın Faculty of Forestry 11(16): 81-94.

[55] Stürmer, S. L., Siqueira, J. O. (2011): Species richness and spore abundance of arbuscular mycorrhizal fungi across distinct land uses in Western Brazilian Amazon. - Mycorrhiza 21: 255-267.

[56] Tisdall, J. M., Oades, J. M. (1982): Organic matter and water-stable aggregates in soils. European Journal of Soil Science 33: 141-163.

[57] Topay, M. (2003): Bartın-Uluyayla Peyzaj Özelliklerinin Rekreasyon-Turizm Kullanımları Açısından Değerlendirilmesi Üzerinde Bir Araştırma. - Doktora Tezi, Ankara Üniversitesi, Fen Bilimleri Enstitüsü, Peyzaj Mimarlığı Anabilim Dalı, Ankara, Türkiye.

[58] Walkley, A., Black, A. I. (1934): An examination of the Degtjareff method for determining soil organic matter, and proposed modification of the chromic acid titration method. - Soil Science 37: 29-38.

[59] Zar, J. H. (1984): Biostatistical Analysis. - Prentice-Hall, Englewood Cliffs, NJ.

[60] Zhang, Y., Gui, L. D., Liu, R. J. (2004): Survey of arbuscular mycorrhizal fungi in deforested and natural forest land in the subtropical region of Dujiangyan, southwest China. - Plant and Soil 261: 257-263.

[61] Zubek, S., Błaszkowski, J., Seidler-Łożykowska, K., Bąba, W., Mleczko, P. (2013): Arbuscular mycorrhizal fungi abundance, species richness and composition under the monocultures of five medicinal plants. - Acta Scientiarum Polonorum Hortorum Cultus 12: 127-141.

[62] Zubek, S., Majewska, M. L., Błaszkowski, J., Stefanowicz, A. M., Nobis, M., Kapusta, P. (2016): Invasive plants affect arbuscular mycorrhizal fungi abundance and species richness as well as the performance of native plants grown in invaded soils. - Biology and Fertility of Soils 52: 879-893. 